\title{
O IDEÁRIO DA REFORMA DO NOVO CÓDIGO DE PROCESSO CIVIL: A REFORMULAÇÃ̃O DO ESPAÇO PRIVADO E AS POLÍTICAS PÚBLICAS DE TRATAMENTO ADEQUADO DE CONFLITOS
}

\section{THE IDEOLOGY OF NEW CODE OF CIVIL PROCESS REFORM: THE REFORMULATION OF PRIVATE SPACE AND PUBLIC POLICY OF APPROPRIATE CONFLICT RESOLUTION}

\begin{abstract}
${ }^{1}$ Zélia Prates Aguiar
${ }^{2}$ Adriana Silva Maillart

RESUMO

O estudo analisa a Reforma do Novo Código de Processo Civil no que concerne à propagação de políticas adequadas de resolução de conflitos e sua efetiva interferência no espaço privado a fim de modificar a cultura do litígio imperante e a intervenção do privado no espaço público pela utilização de políticas hábeis a fazer lei entre as partes e afastar a tutela jurisdicional. A hipótese inicial é que a reformulação processual teria o condão de modificar a cultura brasileira ao tratar adequadamente os conflitos. A pesquisa utiliza o método de abordagem hipotético-dedutivo, fontes bibliográficas e documentais e o procedimento tipológico.
\end{abstract}

Palavras-chave: Novo código de processo civil, Métodos adequados de resolução de conflitos, Público, Privado

\begin{abstract}
The study analyzes the Reform of the New Brazilian Civil Process Code regarding the spread of appropriate conflict resolution policies and their effective interference in the private space in order to modify the dispute prevailing culture and private intervention in the public space for the use of skillful policies to make law between the parties and exclude the judicial protection. The initial hypothesis is that the procedural overhaul would have the power to modify the Brazilian culture to properly handle conflicts. The research uses the hypotheticaldeductive method of approach based on bibliographical and documentary sources and the typological procedure.
\end{abstract}

Keywords: New code of civil procedure, Appropriate methods of conflict resolution, Public, Private

\footnotetext{
${ }^{1}$ Mestranda em Direito, linha de pesquisa Justiça e o Paradigma da Eficiência, no Programa de Mestrado em Direito da Universidade Nove de Julho, UNINOVE - SP , (Brasil). Advogada. E-mail: zeliaprates2010@ gmail.com ${ }^{2}$ Doutora em Direito pela Universidade de Santa Catarina, UDESC - SC, (Brasil). Coordenadora, professora permanente e pesquisadora do programa de Mestrado da Universidade Nove de Julho, UNINOVE - SP, (Brasil). Email: adrissilva@gmail.com
} 


\section{INTRODUÇÃO}

A Reforma do Código de Processo Civil brasileiro dedicou-se veementemente à implementação de políticas públicas de resolução pacífica de controvérsias, tais como a mediação e a conciliação. Diversos artigos do Código foram alterados ou acrescentados priorizando a utilização de tais métodos, inclusive, extinguindo os ritos sumário e ordinário a fim de que a audiência de conciliação seja o primeiro ato composto pelas partes.

A Comissão de Juristas encarregada de elaborar o Anteprojeto do Novo CPC privilegiou os métodos consensuais por acreditar que eles podem otimizar o relacionamento social com larga eficiência em relação à prestação jurisdicional, que coaduna com o II Pacto Republicano de Estado e com os ditames da Resolução n. 125 do Conselho Nacional de Justiça, atendendo também os anseios da Reforma Geral do Poder Judiciário. A Resolução n. 125, em específico, dispõe sobre o tratamento adequado dos conflitos de interesses no âmbito do Poder Judiciário e está fundamentada no artigo 37 da Constituição Federal, que prima pela eficiência operacional, bem como na responsabilidade social e no artigo $5^{\circ}, \mathrm{XXXV}$, da Constituição que assegura o acesso à justiça que, conforme a Resolução, implica em acesso à ordem jurídica justa.

O Novo Código de Processo Civil, assim, indo ao encontro imbuído do desejo de disseminação dos métodos ditos alternativos de resolução de conflitos, priorizou e multiplicou as possibilidades para a solução pacífica das controvérsias, inclusive determinando que a citação do réu será para comparecer em audiência de conciliação sem sequer receber contrafé.

A problemática deste trabalho consiste em analisar se a Reforma Processual Civil, implementando as Políticas Públicas Adequadas de Resolução de Conflitos, estaria apta a promover alteração no espaço privado com a substituição da cultura do litígio pela cultura da pacificação social.

Como hipótese inicial será adotada a premissa de que, no Brasil, a legislação, neste caso, é eficaz para modificação das condutas sociais. Neste sentido, as alterações ocorridas no diploma legal em comento seriam aptas a alterar a cultura social pela utilização dos ADRs (Alternative Dispute Resolution).

Busca-se, para tanto, analisar a influência do espaço público no privado por meio da alteração legislativa e suas consequências e, em via de mão dupla, analisar a consequente "invasão" do espaço público pelo privado que ocorre ao se utilizar os métodos adequados de 
resolução de conflitos estabelecendo-se leis entre as partes e distanciando-se da prestação jurisdicional.

O primeiro tópico ocupar-se-á da análise da Reforma no Código de Processo Civil no que concerne às políticas de resolução de controvérsias, destacado as principais alterações e averiguando sua pertinência.

No segundo, pôr-se-á em cheque o ideário de modificação da esfera privada pelo público que intenta na erradicação/minimização da cultura do litígio e estímulo a uma sociedade mais autônoma, apta a resolver seus conflitos sem a intervenção estatal.

O terceiro tópico, por sua vez, examinará a consequente reformulação do espaço público decorrente da autonomia concedida às partes pelo emprego dos meios alternativos de resolução de litígios permitindo-lhes fazer leis entre elas e, por assim dizer, dizer seu direito.

O estudo pautar-se-á no método de abordagem hipotético dedutivo com base em pesquisas bibliográficas e documental. Adotar-se-á como marco teórico a obra "A Condição Humana” de Hannah Arendt, para averiguar a interferência do espaço privado pelo público e vice-versa.

\section{A Reforma do Código de Processo Civil e as políticas de resolução de conflitos}

O capítulo I do Novo CPC, destinado às normas fundamentais do processo civil, reproduz, no art. $3^{\circ}$, o princípio constitucional da inafastabilidade da jurisdição ${ }^{1}$ em caso de lesão ou ameaça de lesão a direito. Assevera a legalidade da arbitragem e determina que o Estado deverá promover a resolução pacífica de controvérsias, sempre que possível. Disciplina ainda que, os métodos consensuais deverão ser estimulados, por juiz, advogados, defensores públicos e membros do Ministério Público, o que se denomina modelo cooperativo de processo.

\footnotetext{
${ }^{1}$ Constituição Federal. Art. 5 XXXV: a lei não excluirá da apreciação do Poder Judiciário lesão ou ameaça a direito;
} 
A respeito desta nova concepção de processo, assevera Humberto Dalla Bernardina de Pinho que (2011):

Em primeiro lugar, é preciso enfatizar, como aliás tem sido exaustivamente repetido pelo Presidente da Comissão de Juristas encarregada do trabalho, Min. Luiz Fux, que não se trata de uma grande reforma, mas, sim, de um novo Código. Há uma nova ideologia, um novo jeito de compreender o processo civil.

Para efetivar tal determinação no rol de deveres do magistrado em que antes estava previsto apenas "tentar, a qualquer tempo, conciliar as partes" 2 atualmente têm-se a autocomposição a ser proposta a qualquer tempo preferencialmente será feita com o auxílio de conciliadores e magistrados, ao que parece em uma tentativa de, tendo em vista a relevância do tema, que os profissionais sejam capacitados para tanto, mas também atribuindo o sucesso da implementação dos métodos consensuais a todos os operadores do Direito.

Os conciliadores e mediadores judiciais foram contemplados na Seção V do Novo Código de Processo Civil que prevê a criação de centros judiciários de solução de conflitos pelos tribunais para a realização de audiências e sessões de conciliação e mediação bem como desenvolver programas destinados a auxiliar, orientar e estimular a autocomposição.

Mediadores e conciliadores foram incluídos no rol de auxiliares da justiça que antes contemplava os auxiliares do juízo de modo geral, escrivães, oficiais de justiça, peritos, depositários, administrados e intérpretes. Na nova redação do artigo 149, mediadores e conciliadores foram inseridos da mesma maneira que os chefes de secretarias, partidores, tradutores, distribuidores, contabilistas e reguladores de avarias.

Cuidou bem o diploma em comento de diferenciar a mediação da conciliação, esta sendo definida no art. $165, \S 2^{\circ}$ como adequada nos casos em que não houver vínculo anterior entre as partes. Já a mediação fica prevista no $\S 3^{\circ}$ do mesmo artigo, indicada nos casos de relação continuada incumbindo ao mediador auxiliar as partes a compreenderem as questões e os interesses em conflitos a fim de restabelecer a comunicação possibilitando-lhes identificar as possíveis soluções dos conflitos.

\footnotetext{
${ }^{2} \mathrm{CPC} / 73$. Art. 125, inciso IV, IV - tentar, a qualquer tempo, conciliar as partes
} 
Ressalvados estão também os princípios da independência, imparcialidade, autonomia da vontade, confidencialidade, oralidade, informalidade e decisão informada. A exemplo da maior liberdade concedida às partes preceitua o art. $166, \S 4^{\circ}$, que a mediação e conciliação serão regidas de acordo com a autonomia dos interessados, inclusive no que tange à definição de regras procedimentais.

hipótese de não se admitir composição, conforme inciso II. No caso de litisconsórcio, o desinteresse na realização da audiência deve ser manifestado por todos os litisconsortes.

A ausência das partes à audiência será considerada ato atentatório à dignidade da justiça cuja penalidade poderá chegar até dois por cento da vantagem econômica pretendida ou do valor da causa a ser revertida em favor da União ou do Estado. Advogados e/ou defensores deverão acompanhar as partes na audiência sendo possível constituir representante com poderes para transigir ou negociar.

Na audiência de instrução de julgamento, conforme art. 358, o juiz após apregoar os advogados e as partes e instalar a audiência tentará conciliar as partes, a despeito da utilização anterior de outros métodos consensuais de resolução de conflitos como mediação e arbitragem.

No capítulo $X$, destinado às ações de família, em razão das peculiaridades e da complexidade dos relacionamentos familiares, o Código preceitua que todos os esforços deverão ser empreendidos para que o conflito seja solucionado consensualmente, devendo o juiz dispor do auxílio de profissionais de outras áreas do conhecimento para a mediação e a conciliação. Sendo permitido, a requerimento das partes, que o magistrado suspenda o processo para que participem de mediação extrajudicial ou de atendimento multidisciplinar.

Pelas especificidades do direito de família, o art. 696, determina que "a audiência de mediação e conciliação poderá dividir-se em tantas sessões quantas sejam necessárias para viabilizar a solução consensual, sem prejuízo de providências jurisdicionais para evitar o perecimento do direito". A obrigatoriedade de tentar a mediação/conciliação, diz respeito apenas a instauração da audiência de mediação ou conciliação, não sendo obrigatória a firmação de um acordo como se pode deduzir da redação do art. 697 que prevê que: "Não realizado o acordo, passarão a incidir, a partir de então, as normas do procedimento comum, observado o art. 335”. Assim, não há o ferimento do art. 5, XXXV da Constituição Federal como alguns poderiam aduzir, pois a autodeterminação, ou seja, o poder decisório de se chegar a um acordo ou não, fica preservada. Outro ponto importante, quando se trata dos 
acordos relativos à direito de família, é a intervenção do Ministério Público quando houver interesse de incapaz.

Outra situação em que a audiência de mediação é obrigatória, são os casos relativos a litígios coletivos envolvendo a posse de imóveis, quando o esbulho ou a turbação alegada na petição inicial houver ocorrido há mais de ano e dia. Assim sendo, o juiz deverá, antes mesmo de avaliar o pedido de liminar, designar audiência de mediação. O Ministério Público será necessariamente intimado para esta audiência, assim como a Defensoria Pública, se alguma parte for beneficiária de gratuidade da justiça.

Outro importante passo na implementação da solução consensual de controvérsias, é a previsão no art. 172 do Novo Código da utilização destes meios no âmbito administrativo, que possui a finalidade de: I - dirimir conflitos envolvendo órgãos e entidades da administração pública; II - avaliar a admissibilidade dos pedidos de resolução de conflitos, por meio de conciliação, no âmbito da administração pública; III - promover, quando couber, a celebração de termo de ajustamento de conduta. O mesmo dispositivo, ipsis literis, foi previsto no art. 32 da Lei de Mediação brasileira.

A criação de cadastro nacional de mediadores também foi disposta bem como aferição de dados contendo o número de processos em que participou, índice de sucessos e insucessos que serão publicados anualmente para fins estatísticos e de avaliação da conciliação, mediação, câmaras privadas de mediação e conciliação, dos conciliadores e mediadores (art. 167, §4).

Verifica-se, desta maneira, que a implementação dos métodos consensuais de resolução de litígios está presente nas mais diversas fases processuais e tem preferência à solução adjudicada. Tal responsabilidade, conforme o Código, deve ser dividida entre todos os operadores do direito sempre com o auxílio de profissional habilitado.

A abrangência atual e diversas possibilidades de utilização de tais meios objetivam mudar a cultura de litigiosidade brasileira por meio de concessão de autonomia às partes ${ }^{3} \mathrm{e}$ difundir a cultura da pacificação social pelas vias consensuais.

\footnotetext{
${ }^{3}$ Como apontam Adriana Silva Maillart e Samyra Dal Farra Naspolini Sanches (2011, p. 13), "apesar de a autonomia privada ser vista como um princípio de ordem política e, mais concretamente, um princípio de ordem político-liberal, hoje ela não apenas é um princípio puramente político, nem, principalmente, um princípio puramente liberal. Como explica Perlingieri, ela 'abrange todas as liberdades pessoais garantidas constitucionalmente. Nesse sentido, a autonomia privada não se exprime apenas nos negócios jurídicos, mas também através da própria identidade do indivíduo dentro da órbita dos valores hierarquicamente dispostos na Constituição, destacando-se no caso da Constituição de $1988, \quad$ os arts. $5^{\circ}, \quad 6^{\circ}$ e $7^{\circ}$,
} 


\title{
2. O ideário de modificação da esfera privada com a erradicação/minimização da cultura do litígio
}

A complexidade das relações humanas, devido a processos de mudanças sociais e culturais, aumenta o conflito entre as pessoas. Tais conflitos, nas palavras de Dora Fried Schnitman (1999, p. 17), "podem ser percebidos como um aspecto indesejável ou como uma oportunidade de mudança".

Neste contexto, a autora ressalta a utilidade, por assim dizer, dos conflitos advindos das relações humanas. No entanto, assevera ainda a posição cultural que se tem em relação ao meio de solução das controvérsias.

\begin{abstract}
Nossa cultura privilegiou o paradigma ganhar-perder, que funciona com uma lógica determinista binária, na qual a disjunção e simplificação limitam as opções possíveis. A discussão e o litígio - como métodos para resolver diferenças - dão origem a disputas nas quais usualmente uma parte termina "ganhadora", e outra, "perdedora". (SCHNITMAN, 1999, p. 17)
\end{abstract}

No que concerne a essa forma de resolver os problemas, avalia a autora, como algo que empobrece o espectro de soluções possíveis, dificulta a relação entre as pessoas envolvidas e gera custos econômicos, afetivos e relacionais.

A despeito do disposto por Schnitman, o fato é que os conflitos têm sido resolvidos adjudicadamente pela requisição de provimento jurisdicional do Estado-Juiz, o que acarreta sobrecarga do Sistema Judiciário. A este respeito explica Kazuo Watanabe (2015, p. 2),

\footnotetext{
O mecanismo predominantemente utilizado pelo nosso Judiciário é o da solução adjudicada dos conflitos, que se dá por meio de sentença do juiz. E a predominância desse critério vem gerando a chamada "cultura da sentença", que traz como consequência o aumento cada vez maior da quantidade de recursos, o que explica o congestionamento não somente das instâncias ordinárias, como também dos Tribunais Superiores e até mesmo da Suprema Corte. Mais do que isso, vem aumentando também a quantidade de execuções judiciais, que sabidamente é morosa e ineficaz, e constitui o calcanhar de Aquiles da Justiça.
}

A cultura da sentença reinante decorre, dentre outros fatores, da situação histórica brasileira advinda de uma colonização que objetivou tão somente extrair as riquezas do país e 
enviá-las à coroa, bem como do severo regime de escravidão em que o negro apenas poderia pleitear os poucos direitos que detinha pelo acionamento da máquina estatal.

\begin{abstract}
O escravo é um ente privado dos direitos civis; não tem o de propriedade, o de liberdade individual, o de honra e reputação; todo o seu direito como criatura humana reduz-se ao da conservação da vida e da integridade do seu corpo; e só quando o senhor atenta contra este direito é que incorre em crime punível. (Recurso apresentado em 1879 à Relação do Maranhão) (CASTRO, 1997, p. 338)
\end{abstract}

Do trecho acima transcrito depreende-se que, apesar de delimitadas hipóteses, o escravo poderia ter seus direitos de conservação da vida e da integridade de seu corpo resguardados ainda que em face de seu senhor.

Em 1981 fora promulgada a primeira Constituição do período republicano, no entanto, apesar de assegurar em seu texto a inviolabilidade do direito à liberdade, bem como a igualdade de todos perante a lei, os direitos sociais restringiam-se à essa igualdade formal, pois não se efetivava a fim de coadunar com os anseios sociais. A população vivia em situação de extrema pobreza, exemplo dessa realidade foi a Guerra de Canudos ${ }^{4}$ que ocorreu de 1896 a 1897 em que o povo liderado por Antônio Conselheiro negou-se a pagar os impostos "punindo os pecados republicanos" e intentou criar uma sociedade sem diferenças sociais. O movimento foi exterminado depois de quatro tentativas não sendo poupados nem idosos, mulheres e crianças.

Neste sentido, verifica-se a importância de a lei atender sua função precípua de finalidade social, de expressão dos anseios da sociedade e de ser efetiva com vistas a evitar situações como a ocorrida na Guerra de Canudos, em que o povo foi massacrado por exigir o que lhes era assegurado por direito na Carta Constitucional.

O perigo dos desmandos estatais também se verificou em 1904 com a Revolta da Vacina no Rio de Janeiro quando o governo criou campanha obrigatória de vacinação contra a varíola. Isso porque, se impôs a vacinação sem a implementação de políticas públicas de conscientização da população a respeito dos efeitos positivos da vacina. Desconhecendo tais efeitos a população pobre e desinformada enfrentaram as forças do governo em vários conflitos.

A desconfiança do governo decorria em grande escala do fato de desalojar diversas pessoas de cortiços e habitações populares para a construção de avenidas, jardins e prédios modernos no que se denominou Reforma Urbana da Cidade do Rio de Janeiro. 
Após severos confrontos, a paralisação da vacinação obrigatória, a decretação do estado de sítio da cidade, várias prisões, deportações para o Acre, cerca de 30 mortos e 100 feridos, a situação foi controlada e a vacinação obrigatória retomada, consequentemente a varíola erradicada do Rio de Janeiro.

Nisto verifica-se a importância de integração entre a lei, anseios sociais e as políticas públicas para difundir as medidas, seus benefícios e intentos, pois, em que pese a medida por vezes ser boa e até necessária a imposição da sociedade ao cumprimento dela pode não permitir que se alcance o intento pretendido.

O Estado Novo, em que a legislação trabalhista assegurava direito apenas à parcela operária da população excluindo os trabalhadores do campo, constituiu marcante cenário de desigualdade e previsão legal que não refletia os anseios sociais.

Brodwyn Fisher (2006, p. 417) relata que milhares de cartas foram enviadas ao Presidente Vargas retratando a situação dos trabalhadores rurais que incapacitados para o trabalho enfrentavam extrema miséria e, por vezes ainda perdiam suas terras. As súplicas das cartas retratavam pessoas que pediam clemência, pois legalmente nada lhes era assegurado apesar de contribuírem para a riqueza do país e sustento da população.

A autora transcreve trechos da carta enviada por Rosario Patané, trabalhador rural, escrita em 1939, enquanto estava hospitalizado acometido por "fatal moléstia" no pulmão que retrata a situação dos trabalhadores não protegidos pela legislação.

\begin{abstract}
“(...) com Vossa inteligente organização social, fizeste com que, todas e qualquer camada social trabalhadora do País, goze de uma tal garantia que não há atualmente ser humano no Brasil que fique ao léu da sua sorte, quando por infelizidade fica invalidado para o serviço [...]", no entanto, "há ma classe de trabalhadores que ficou a margem da Lei [...]", pessoas que "alimentam todos os demais, e [...] cooperam com a parcela do seu trabalho, para a grandeza do Brasil” (FISCHER, 2006, p. 418).
\end{abstract}

O progresso trabalhista decorrente das alterações legislativas propostas por Vagas não está aqui colocado em cheque ou desmerecido, mas sua destinação exclusiva à parcela da população que era operária contribuiu veementemente para o aumento das desigualdades sociais e exemplifica a distância entre as necessidades sociais e as determinações legais.

\footnotetext{
${ }^{4}$ Sobre a Guerra de Canudos ver: "Os Sertões” de Euclides da Cunha.
} 
O período de ditadura militar imperante no Brasil de 1964 a 1985, por conta das severas perseguições realizadas inclusive pelo Estado ou com a anuência deste ou por sua falsa cegueira, estimulou a Constituição de 1988 a determinar, seguindo a Constituição de 1946 e 1967, no art. 5, inciso XXXV, a inafastabilidade do Estado à lesão ou ameaça de lesão a direitos. Tal dispositivo garante o direito de ação e o dever do Judiciário de atender aos pleitos que rompem com a inércia jurisdicional ${ }^{5}$.

A discussão inicial existente a respeito dos métodos consensuais de resolução de conflitos era se tal utilização não violaria o preceito constitucional do dispositivo mencionado. No julgamento que avaliou a constitucionalidade do efeito negativo da convenção de arbitragem livremente pactuada no Supremo Tribunal Federal, destaca-se o voto do Ministro Nelson Jobim, em 2001, no julgamento do Agravo Regimental em Sentença Estrangeira:

(...) Em primeiro lugar, examinando o dispositivo constitucional através da perspectiva do seu núcleo normativo, e verificando o caráter desse dispositivo, vemos desde logo, que o dispositivo é proibitivo da existência ou da criação de mecanismos que excluam da apreciação do Poder Judiciário lesão a direito ou ameaça a direito; em segundo, o destinatário da norma não é o cidadão, mas, sim, o sistema legal, ou seja, é proibido ao sistema legal criar mecanismos que excluam da apreciação do Poder Judiciário lesão ou ameaça a direito. (...) Portanto, se o destinatário da norma é o legislador, preservou-se ao cidadão o direito de opção e não a obrigatoriedade do cidadão de compor os seus conflitos pela vida judicial. Abre-se ao cidadão, portanto, o respeito à sua liberdade; a liberdade de tentar compor os seus conflitos fora da área do poder judiciário. (...) (Agravo Regimental em Sentença Estrangeira no $5206-7$ ES)

Tal discussão fora devidamente pacificada e os métodos autocompositivos difundidos, especialmente após a criação pela Emenda Constitucional 45/2004, denominada de Reforma do Judiciário.

\footnotetext{
5 “José Maria Rossani Garcez também contribui para se elucidar o verdadeiro motivo da inserção do art. $5^{\circ}$, XXXV como dispositivo constitucional. Alega o autor que o referido artigo 'remonta aos tempos do Estado Novo, em que o regime ditatorial fazia com que os inquéritos parlamentares e policiais fossem levados a efeito sem que os envolvidos tivessem assegurado direito e garantias mínimas, sendo vedado ao Judiciário o reexame da questão'. Acrescenta ainda que, 'neste contexto, no regime de 1937, justificou-se o preceito inserido na CF de 1946 em razão da legislação existente, excludentes de apreciação judicial inquéritos parlamentares e policiais, prevendo não poder a lei excluir à apreciação do Poder Judiciário a lesão ou ameaça de direito, sendo ele mantido nas Cartas de 1967 e 1988, quase com a mesma redação', para ter-se determinado qual o objetivo primeiro do referido dispositivo constitucional" (SILVA, 2005, p. 160-161).
} 
A Reforma, que priorizou, dentre outras assertivas, a utilização de meios alternativos de solução de controvérsias e que foi ressaltada no II Pacto Republicano de Estado, assinado pelos três Poderes da Federação em 2009, em que, dentre os compromissos assumidos, constava o de “[...] Fortalecer a mediação e a conciliação, estimulando a resolução de conflitos por meios autocompositivos, voltados a maior pacificação social e menor judicialização", com o objetivo de criar um sistema de justiça mais acessível, ágil e efetivo. A Reforma inclusive indicou a necessidade de alterações no processo civil, visando, entre outros fatores, a solução de controvérsias por métodos complementares de solução de disputas, associando o acesso à justiça para além do acesso único ao Poder Judiciário.

O Pacto Republicano também ressaltou a colaboração efetiva dos três Poderes na realização de indispensáveis reformas processuais e atualização de normas legais e da prioridade para o Poder Executivo, desde a criação da Secretaria de Reforma do Judiciário no Ministério da Justiça, do exercício das atribuições de colaborar, articular e sistematizar propostas de aperfeiçoamento normativo e acesso à Justiça.

Uma destas modificações, em prol da utilização de meios autocompositivos de solução de controvérsias, foi a edição da Resolução n. 125, do Conselho Nacional de Justiça (CNJ), Conselho criado pelos movimentos de Reforma do Judiciário.

A Resolução n. 125, publicada pelo CNJ em 29 de novembro de 2010, instituiu a política pública de tratamento adequado de conflitos e priorizou a utilização de métodos autocompositivos, tais como a conciliação e a mediação, para a solução de controvérsias, mas, sobretudo, os considerando instrumentos efetivos de pacificação social.

Entretanto, o ano de 2015 foi marco na implementação das políticas de resolução de conflitos paralelas à apreciação jurisdicional, com a promulgação do Código de Processo Civil, da alteração da Lei de Arbitragem (n 13.129/2015) e da aprovação da Lei de Mediação $\left(n^{\circ} 13.140 / 2015\right)$. Ao que parece, o Estado incapaz de cumprir sua missão de pacificação social tenta dividir com jurisdicionado a responsabilidade de pacificar a sociedade.

Utiliza-se, assim, a legislação para modificar a cultura social sem considerar os anseios sociais que, idealmente, deve preceder as normas. Não cabe ao direito modificar a sociedade, ainda mais tendo em vista o processo legislativo, cabe-lhe acompanhar as mudanças sociais e adequar-se a elas, mantendo-se atual.

O papel das leis na antiguidade era diverso do atual, principalmente em decorrência do processo de elaboração. Assevera Hannah Arendt (2007, p. 73), que antes incumbia à lei 
dividir a esfera pública da privada e protegê-las. No entanto, ressalta a respeito da diferença da lei da polis da atual.

\begin{abstract}
A lei era originalmente identificada como esta linha divisória que, em tempos antigos, era ainda na verdade um espaço, uma espécie de terra de ninguém entre o privado e o público, abrigando e protegendo ambas as esferas e ao mesmo tempo separando-as uma da outra. É verdade que a lei da polis transcendia esta antiga concepção da qual, no entanto, retinha a importância espacial original. A lei da cidade-estado não era nem o conteúdo da ação política (a ideia de que a atividade política é fundamentalmente o ato de legislar, embora de origem romana, é essencialmente moderna e encontrou sua mais alta expressão na filosofia política de Kant) nem um catálogo de proibições, baseado como ainda o são todas as leis modernas, nos "Não Farás" do Decálogo. Era bem literalmente um muro, sem o qual poderia existir um aglomerado de casa, um povoado (asty), mas não uma cidade, uma comunidade política. Essa lei de caráter mural era sagrada, mas só o recinto delimitado pelo muro era político.
\end{abstract}

A determinação de tais normas, a despeito do caráter útil e louvável que se possa ter, incorre na séria invasão do espaço privado pelo público. Não basta a invasão diuturna que ocorre na esfera econômica apesar da determinação constitucional, de postura indicativa na economia e de prestação de serviços públicos. Nas palavras de Irene Nohara (2015, p. 36):

\begin{abstract}
A substituição da gestão pública, antes vista como uma atividade ligada aos fins, e a sua "entrega" nas mãos da iniciativa privada provoca a retração do Estado no controle dos serviços públicos, o que acaba mitigando a orientação constitucional de que o planejamento estatal neste âmbito deve ser determinante, conforme previsão do art. 174, caput, da Constituição. Paradoxalmente, diversos setores da iniciativa privada, num cenário de permanente crise e escassez, acabam sendo progressivamente controlados pelo Estado.
\end{abstract}

A efetividade de tal imposição pode até gerar bons frutos, mas não se deve atribuir a sobrecarga do sistema jurídico falido à população sem considerar o Relatório dos 100 maiores litigantes elaborado pelo Conselho Nacional de Justiça (2011) no qual a primeira classificação é ocupada pelo Poder Público, seguido pelos bancos e intuições financeiras e as empresas de telefonia.

Não se objetiva aqui retirar o mérito e os pontos positivos dos meios consensuais de resolução de conflitos e sim atentar para o fato de que o público, apesar do grande histórico de desrespeito do privado, não deve estabelecer leis para ordenar mudanças sociais, antes, deve elaborar uma política educativa de disseminação de tais métodos.

Importa ainda atentar-se, em breve análise, para a forma de efetivação das mencionadas audiências de conciliação: será o prazo de espera de agendamento compatível com o princípio constitucional da razoável duração do processo? De igual modo, os Centros Judiciários até então criados teriam estrutura adequada a realizar todas essas sessões? De fato, se dará preferência pela realização das audiências/sessões pelos conciliadores e mediadores? 
Tais indagações deixam em dúvida a capacidade de o Judiciário concretizar o previsto na norma processual civil reformada e o povo arcará com o preço, pois, em cumprimento da norma, esperar-se-á o trâmite processual correto.

Novamente, ressalta-se que não se intenta subverter os valores dos meios aqui analisados, mas averiguar a capacidade institucional de efetivação de medidas que impostas ao povo podem, sem o devido aparato necessário, terem efeito contrário promovendo repulsa pelos métodos adequados de resolução de conflitos.

\footnotetext{
(...) não é realmente exato dizer que a propriedade privada, antes da era moderna, era vista como condição axiomática para admissão à esfera pública; ela era muito mais que isso. A privatividade era como que o outro lado escuro e oculto da esfera pública; ser político significava atingir a mais alta possibilidade da existência humana; mas não possuir um lugar próprio e privado (como no caso do escravo) significava deixar de ser humano. (ARENDT, 2007, p. 74)
}

A importância da conservação do espaço privado foi bem definida por Hannah Arendt no trecho acima. $\mathrm{O}$ direito a ter o espaço privado está intimamente ligado à condição de ser humano e a ausência de tal situação acarretaria condição semelhante à do escravo em que tudo que se tem a sua volta é público.

\section{A reformulação do espaço público pelo privado por meio da utilização dos métodos adequados de resolução de litígio}

A confusão entre o espaço público e privado no Brasil encontra registro na conhecida afirmação de frei Vicente de Salvador. Segundo o autor, no Brasil "nem um homem [...] é republico, nem zela ou trata do bem comum, senão cada um do bem particular [...] [pois] nesta terra andam as coisas trocadas, porque toda ela não é república, sendo-o cada casa" (LARA, 2006, p. 60).

Para Silvia Hunold Lara (2006, p. 60 e 61), em que pese a passagem se referir ao empenho dos reis de Portugal em arrecadar tributos e aos povoadores de extrair riquezas e enviar à coroa e alguns autores acreditarem se tratar de crítica à exacerbação do poder privado em detrimento da ordem pública nas áreas coloniais, sua abrangência é mais ampla, pois diz respeito "a um dos dilemas mais importantes da prática política do antigo regime: o do equilíbrio entre os poderes públicos e privados".

O público e o privado não eram vistos como opostos, apesar da realidade de diferenças determinadas pelo nascimento, em graus diversos todos tinham direitos e obrigações, direitos e privilégios. As leis e tratados portugueses dos séculos XVII e XVIII 
costumeiramente exprimiam o objetivo do monarca em "fazer justiça" e "zelar pelo bem comum".

Os excessos pelo público e privado, a bem da verdade, tal como se verificou em meados do século XVII, "perturbava o exercício da vontade real, colocava em risco a cadeia hierárquica da delegação de poderes e jurisdições e a própria sobrevivência do domínio colonial" (LARA, 2006, p. 62). Enfatiza a autora ainda que para o frei, o desequilíbrio entre as esferas colocava em risco a conservação do Brasil como parte do corpo político português, em termos econômicos, políticos e religiosos.

Sob análise neste trabalho a atual interferência do espaço privado sob o público com a difusão dos meios consensuais de resolução de controvérsias que têm como importante característica, conforme dito anteriormente, a autonomia concedida às partes para resolverem seus conflitos, inclusive no que concerne aos procedimentos utilizados para tanto. Desde que não contrarie a lei e os bons costumes podem as partes disporem livremente a respeito da solução ideal para seus conflitos.

Para Amartya Sen (1999, p.32-33), as razões para a importância da liberdade individual no conceito de desenvolvimento estão relacionadas à sua avaliação e eficácia. Segundo o autor, a liberdade concedida aos membros seria adequada para avaliar o desenvolvimento da sociedade. A eficácia, por sua vez, aqui relacionada à eficácia social, diz respeito aos proveitos que tal liberdade permite no que diz respeito ao desenvolvimento das pessoas.

(...) Primeiro, na abordagem normativa usada neste livro, as liberdades individuais são consideradas essenciais. O êxito de uma sociedade deve ser avaliado, nesta visão, primordialmente segundo as liberdades substantivas que os membros dessa sociedade desfrutam.

(...) A segunda razão para considerar tão crucial a liberdade substantiva é que a liberdade é não apenas a base da avaliação de êxito e fracasso, mas também um determinante principal da iniciativa individual e da eficácia social. Ter mais liberdade melhora o potencial das pessoas para cuidar de si mesmas e para influenciar o mundo, questões centrais para o processo de desenvolvimento.

Neste contexto, é desejável que as pessoas se tornem mais autônomas a fim de se desenvolverem e contribuírem para o êxito da sociedade. O que segundo Sen (1999, p. 33), "é importante para a liberdade global da pessoa e importante porque favorece a oportunidade de a pessoa ter resultados valiosos".

Vale destacar que a liberdade aqui analisada não se finda na liberdade processual e sim na oportunidade que as partes têm de comporem seus litígios, de "fazerem leis entre elas", 
de definirem seus destinos, de acionar o Judiciário se quiserem, em suma, de tornarem-se de fato mais autônomas.

Freire (1996, p. 35) bem desenvolveu a ideia de autonomia ressaltando situação humana de seres inacabados e condicionados. Inacabados por estarem em constante mutação, acréscimos, decréscimos, escolhas que definem o caráter num permanente processo de busca e condicionados, diferente de determinado, que consciente do inacabamento pode ir mais além. “(...) O respeito à autonomia e à dignidade de cada um é um imperativo ético e não um favor que podemos ou não conceder uns aos outros".

O Novo Código de Processo Civil ao difundir os meios de resolução de conflitos no âmbito processual, inclusive assegurando a autonomia das partes, possibilita que a esfera privada (vontade das partes) interfira na esfera pública (leis entre as partes e resolução de litígios).

A interferência do privado no público não é exclusiva de tal fato, muito pelo contrário. A título de exemplo tem-se a grande exposição da vida privada na esfera pública em que os mais íntimos segredos são estampados por aqueles que o deveriam guardar.

Já há algum tempo, a famosa "prova de existência" de Descartes, "Penso, logo existo", tem sido substituída e rejeitada por uma versão atualizada para nossa era de comunicação de massas: "Sou visto, logo existo". Quanto mais pessoas podem escolher me ver, mais convincente é a prova de que estou aqui" (BAUMAN, 2011, p. 28).

Para o autor, o conceito de público e privado foram modificados pelas inovações tecnológicas desencadeando mudanças culturais. Assevera ainda que “(...) a esfera pública (...) se encontra hoje inundada e sobrecarregada, invadida pelos exércitos da privacidade" (BAUMAN, 2011, p. 41)

Dessa forma, verifica-se que a Reforma Processual Civil se trata de uma via de mão dupla em que tanto a esfera pública interfere na privada pela disposição legal de procedimento específico que torna dificultoso não se submeter aos meios ditos alternativos de resolução de controvérsias, quanto a privada interfere na pública pela autonomia inerente à utilização de tais meios em que as partes são mais livres para criarem as soluções que julgarem apropriadas para sanares seus litígios.

A liberdade, princípio almejado pela $2^{\mathrm{a}}$ dimensão de Direitos Humanos, e devidamente protegido pela Constituição Federal no art. $5^{\circ}$, inciso VI, é princípio fundamental do Estado de Direito e deve ser resguardada. No entanto, imperioso se faz relembrar que a solidariedade, princípio propulsou da $3^{\mathrm{a}}$ dimensão de Direitos Humanos, deve ser aliada à 
liberdade para possibilitar uma vida digna aos ditos livres, se assim não fosse nos bastaria, por si só, a liberdade, mas ela deixou às minguas a população que não a poderia exercer plenamente pela situação social em que se inseria.

\section{CONCLUSÃO}

O ideário da Reforma do Novo Código de Processo Civil, no que tange aos meios consensuais de resolução de conflitos, consiste na substituição da cultura da sentença que prima sempre pela decisão adjudicada para findar ao conflito pela cultura da pacificação social que visa conceder autonomia para as partes resolverem seus litígios, desde que não contrarie aos bons costumes, como lhe aprouverem.

Primordial se faz compreender o contexto da alteração legislativa com atenção especial para a Emenda Constitucional 45/2004 que, dentre outras atribuições, criou o Conselho Nacional de Justiça com a atribuição de controlar a atuação administrativa e financeira do Poder Judiciário.

O Sistema Judiciário brasileiro está em crise e padece de morosidade e descrédito, mostra-se incapaz de cumprir a missão que avocou para si de dizer o direito e desobedece ao princípio constitucional da razoável duração do processo, pois os processos, ainda que simples, demoram anos para serem julgados e a perspectiva não é animadora tendo em vista que a cada ano o número de processos distribuídos é maior do que o número de julgados.

Diante da incapacidade jurisdicional de resolver os litígios submetidos à sua apreciação urgente se fez analisar outras formas de resolução de demandas, denominadas meios adequados de resolução de conflitos, e o CNJ, no uso de suas atribuições, resolveu instituir com a Resolução n. 125/2010 a Política Pública de Tratamento Adequado de Resolução de Conflitos.

Determinou a Resolução, afim de efetivar a implementação das medidas, a criação pelos Tribunais de Núcleos Permanentes de Métodos Consensuais de Resolução de Conflitos e que, por sua vez, deveria instalar Centros Judiciários de Solução de Conflitos e Cidadania para realização de sessões de conciliação e mediação.

O Conselho de Reforma Processual Civil, também apoiado nesta nova onda ampliativa de justiça, estabeleceu o processo cooperativo em que juízes, advogados, membros do Ministério Público e defensores públicos deverão promover conjuntamente a utilização dos meios consensuais. 
Perscrutando-se este caminho indagou-se a pertinência da Reforma Processual de, tratando-se da esfera pública, alterar a cultura de resolução de conflitos impondo determinações à esfera privada repassando, em diversos atos processuais, a responsabilidade de resolvê-los às partes.

Em que pese a lei não ser adequada à modificação da sociedade o que se verifica é que, por vezes, é utilizada para tanto, deixando de lado seu papel de responder aos anseios sociais para estabelecer prioridades para a sociedade. Neste sentido, a hipótese inicial de que a Reforma intentada pode modificar a esfera privada se confirma. No entanto, cabe ressalva quanto à forma dessa mudança social que deveria ser instituída por políticas educativas, bem como no que concerne à capacidade do Sistema de cumprir o determinado na legislação processual.

Intentou-se ainda, verificar, como consequência da maior autonomia de vontade concedida às partes, a interferência da esfera privada na pública ao passo que as partes podem resolver seus litígios estabelecendo, desde que não contrariam os bons costumes, leis, por assim dizer, aptas a pôr fim a seus conflitos.

Desse modo, a Reforma Processual que intensificou a possiblidade de utilização dos meios consensuais de resolução de controvérsias sendo ordem pública que interferem no setor privado da qual decorre a autonomia das partes que as permite na esfera privada modificar a pública constitui via de mão dupla, um diálogo pleno entre as esferas público-privada. 


\section{REFERÊNCIAS}

ARENDT, Hannah. A condição humana. Trad. Roberto Raposo. 10 ed. Rio de Janeiro: Forense Universitária, 2007.

BAUMAN, Zygmunt. 44 Cartas do Mundo Líquido Moderno. Rio de Janeiro: Jorge Zahar,

2011.

BRASIL, CONSELHO NACIONAL DE JUSTIÇA. Resolução no 125, de 29 de novembro de 2010. Dispõe sobre a Política Judiciária Nacional de tratamento adequado dos conflitos de interesses no âmbito do Poder Judiciário e dá outras providências. Diário Oficial da República Federativa do Brasil, Brasília, DF, 29 nov. 2010.

BRASIL. Lei $\mathbf{n}^{\mathbf{0}} \mathbf{1 3 . 1 0 5}$, de 16 de março de 2015.

BRASIL. Supremo Tribunal Federal. Agravo Regimental em Sentença Estrangeira $\mathbf{n}^{\mathbf{0}}$ 5206-7 ES. Relator(a): Min. SEPÚLVEDA PERTENCE, Tribunal Pleno, julgado em 12/12/2001, DJ 30-04-2004 PP- 00029 EMENT VOL-02149-06 PP-00958).

CASTRO, Hebe M. de. Laços de Família e Direitos no Final da Escravidão. In: ALENCASTRO. Luiz Felipe de; NOVAIS, Fernando A. (org.). História da Vida Privada no Brasil - Império: à corte e a modernidade nacional. Vol. 2. São Paulo: Companhia das Letras, 1997.

CONSELHO NACIONAL DE JUSTIÇA. Relatório 100 maiores litigantes. 2011. Disponível em: http://www.cnj.jus.br/images/pesquisasjudiciarias/pesquisa_100_maiores_litigantes.pdf

FISCHER, Brodwyn. Direitos por Lei ou Leis por Direitos? Pobreza e ambiguidade legal no Estado Novo. Tradução de Cristina Meneguello. In LARA, Silvia Hunold, MENDONÇA, Joseli Maria Nunes (Org.). Direitos e Justiças no Brasil: Ensaios de História Social.. Campinas: Editora da UNICAMP, 2006.

FREIRE, Paulo. Pedagogia da autonomia - Saberes Necessários à Prática Educativa. São

Paulo: Paz e Terra, 1996.

LARA, Silvia Hunold. Senhores da Régia Jurisdição - O particular e o Público na Vila de

São Salvador dos Goitacases na Segunda Metade do Século XVIII. In. LARA, Silvia Hunold, MENDONÇA, Joseli Maria Nunes (Org.). Direitos e Justiças no Brasil: Ensaios de

História Social. Campinas: Editora da UNICAMP, 2006.

MAILLART, Adriana Silva; SANCHES, Samyra Dal Farra Naspolini. Os limites à liberdade na autonomia privada. In. Pensar Revista de Ciência Jurídicas. Fortaleza, V. 16, n. 1, janjun. 2011, p. 9-34. 
NOHARA, Irene Patrícia. Regulação da atividade econômica na dissolução das fronteiras entre público e privado. Scientia Iuris, Londrina, V. 19, n. 1, p. 29-46, jun. 2015.

PINHO, Humberto Dalla Bernardina de. O novo CPC e a mediação: Reflexões e ponderações. Revista de Informação Legislativa. Brasília: 2011. Disponível em: http://www2.senado.leg.br/bdsf/bitstream/handle/id/242895/000923117.pdf? sequence=1

SCHNITMAN, Dora Fried: LITTLEJHON, Stepleen. (Org.). Novos Paradigmas na Resolução de Conflitos. Porto Alegre: Artmed, 1999.

SEN, Amartya. Desenvolvimento como liberdade. Trad. Laura Teixeira Motta. São Paulo: Companhia das Letras, 1999.

SILVA, Adriana S. Acesso à Justiça e arbitragem: um caminho para a crise do Judiciário. Barueri: Manole, 2005.

WATANABE, Kazuo. Política Pública do Poder Judiciário Nacional para Tratamento Adequado dos Conflitos de Interesse. Disponível em: http://www.tjsp.jus.br/download/conciliacao/nucleo/parecerdeskazuowatanabe.pdf. Acesso em: 22 nov. 2015. 